\title{
Importance of the physicochemical properties of fluorescent dyes for obtaining target-specific in vivo images by membrane-permeable macromolecular imaging probes
}

\author{
Takahiro Kuchimaru', Tetsuya Kadonosono' ${ }^{1}$, Cesear Corona ${ }^{2}$, Stephen J. Dwight ${ }^{2}$, Mark McDougall ${ }^{2}$, Shuntaro Takahashi' \\ Toshiaki Mori ${ }^{1}$, Yoshio Okahata ${ }^{1}$ and Shinae Kizaka-Kondoh ${ }^{1 *}$ \\ *Correspondence: skondoh@bio.titech.ac.jp \\ 'Department of Biomolecular Engineering, Tokyo Institute of Technology Graduate School of Bioscience and \\ Biotechnology, 4259-B60, Nagatsuda-cho, Midori-ku, Yokohama 226-8501, Japan. \\ 2Promega Biosciences, LLC U.S.A., 277 Granada Drive, San Luis Obispo, California, 93420.
}

\begin{abstract}
Background: Membrane-permeable macromolecular (MPM) probes are designed to deliver functional proteins to disease sites and into cells by using protein transduction domain (PTD). To visualize intracellular molecular events in tumor sites, we previously developed MPM imaging probes conjugated with near-infrared fluorescence (NIRF) dyes. However, the factors which influence target-specific in vivo fluorescence images of MPM imaging probes are still unclear. We studied whether the physicochemical properties of NIRF dye significantly affect the in vivo images of MPM imaging probes.

Methods: We constructed three MPM imaging probes conjugated with NIRF dyes including IRDye800, AlexaFluor750 and the newly synthesized PBI3921 and compared their biodistribution in tumor-bearing mice using in vivo optical imaging. In addition, we addressed to reveal relationships between biodistribution of MPM imaging probes and conjugated NIRF properties.

Results: In vivo images obtained by three MPM probes were spatiotemporally different each other. These probes $(\sim 46 \mathrm{kDa})$ are different only in their NIRF dyes $(\sim 2 \mathrm{kDa})$, which have different physicochemical properties including surface charge and hydrophobicity based on chromatograph analyses. Moreover, the results of clearance efficiency obtained by using cancer cells were not necessarily correlated with the ones obtained by using mouse models. Conclusions: We concluded that physicochemical properties of NIRF dyes do affect the in vivo off-target images after injection of MPM imaging probes and that clearance of non-specific image may be predicted by the analysis of the property of a fluorescent dye conjugated to MPMs. These results would provide useful information to design MPM imaging probes with high target specificity in vivo.
\end{abstract}

Keywords: Membrane-permeable macromolecule, In vivo imaging probe, Biodistribution, Near-infrared fluorescence dye, Protein transduction domain

\section{Introduction}

In vivo imaging probes have been developed extensively for preclinical studies and diagnosis of cancers [1,2]. Engineered antibodies are successful macromolecular probes to image cancer cells in vivo [3,4]. However, their targets are limited on the cell-surface components because of poor cell-membrane penetration of macromolecules. Intracellular components contain strong candidates of diagnosis and therapeutic targets, motivating us to develop membrane-permeable macromolecules (MPMs) for imaging intracellular molecules. Recent studies demonstrate that protein transduction domains (PTDs), also known as cell-penetrating peptides, can deliver conjugated macromolecular cargos by penetrating the cell membrane, and they have been utilized as transport vectors in biomedical applications [5-7]. At present, in vivo studies of PTDs are being conducted to deliver proteins, oligonucleotides, siRNA, liposomes, and nanoparticles inside cells where they target disease-specific molecules [8-12]. Therefore, PTD-conjugated macromolecules are promising materials targeting intracellular molecules.

In small animal studies, near-infrared fluorescence (NIRF) technologies have attracted much attention because of the almost complete elimination of background noise caused by tissue autofluorescence and the reduced scattered light from the excitation source [13]. Various long-wavelength fluorescent dyes have been synthesized, with fluorescence maxima ranging from 700 to approximately $850 \mathrm{~nm}$ [14]. We recently developed a functional MPM, PTD-ODD-HaloTag (POH) fusion protein $(46 \mathrm{kDa})$ comprising of 3 domains: a PTD, an oxygen-dependent degradation domain (ODD) corresponding to human hypoxia-inducible factor (HIF) 
-1a (548-603), and a HaloTag (HT) that is easily conjugated with any chemical through covalent binding of $\mathrm{HT}$ and its ligand. The PTD of POH efficiently enables it to enter cells and the ODD allows it to be selectively stabilized in HIF-active cells [15], which are responsible for treatment resistance and malignant progression of tumor hypoxia [16]. $\mathrm{POH}-\mathrm{N}$, a NIRF dye-conjugated $\mathrm{POH}$ successfully imaged HIF-active cells in vitro and in vivo. However, we found that the in vivo biodistribution of $\mathrm{POH}-\mathrm{N}$ was significantly influenced by the NIRF dye component.

For in vivo imaging probes, one of the most important factors to achieve target-specific imaging in whole-body is quick clearance of the off-target signals from the excretory organs such as the kidneys and liver. Furthermore, MPM imaging probes have to be quickly cleared from the nontargeted tissue cells by the cellular excretion system after entering cells. Thus, both excretion systems must be studied to optimize the in vivo distribution of MPM imaging probes. Although there are some in vivo biodistribution studies for PTD-containing therapeutic probes indicating that a cargo of probes influences the excretion process of the probes in vivo [17,18], no study has been reported for MPM imaging probes.

In the present study, we have attempted to elucidate the decisive factors in NIRF dyes influencing the in vivo images of MPM imaging probes by using three different $\mathrm{POH}-\mathrm{Ns}$. The results indicate that the physicochemical property of NIRF dyes such as electrical charge distribution and relative hydrophobicity strongly influences the rates of membrane-penetration and in vivo off-target images after injection of $\mathrm{POH}-\mathrm{Ns}$.

\section{Materials and methods \\ Preparation of the $\mathrm{POH}$ protein}

$\mathrm{POH}$ protein $(46 \mathrm{kDa}$ ) was prepared as described previously [15]. Briefly, the plasmid POH/pGEX-6P-3 encodes PTD-ODDHaloTag7 protein $(\mathrm{POH})$, which consists of polypeptides indicated in (Supplement figure S1). The $\mathrm{POH}$ protein was expressed in BL21-CodonPlus cells (Stratagene, La Jolla, CA, USA) as a GST-tagged protein. The GST-tagged protein was purified with a GST-column and then digested with precision protease (GE healthcare Bio-Science Corp., Piscataway, NJ, USA) to remove GST-tag from the fusion protein. The final product was equilibrated in $\mathrm{Mg}^{2+}-/ \mathrm{Ca}^{2+}$ free PBS (pH 8.0).

\section{Preparation of the $\mathrm{POH}-\mathrm{N}$ probes}

The HaloTag ligand-near infrared fluorescence dye (HL-N), HaloTag ligand-PBI3920 (HL-P) (Molecular weight: 1350.09) and HaloTag ligand-IR800 (HL-I) (Molecular weight: 1297.01), were provided by Promega Corporation (Madison, WI, USA). HaloTag ligand-Alexa Fluor 750 (HL-A) (Molecular weight: 1800) was prepared as described previously [15]. Synthesis procedure of HL-P was indicated in the supporting information. $\mathrm{HL}-\mathrm{N}(100 \mathrm{nmol})$ was dissolved in $20 \mu \mathrm{L}$ of DMF.
$\mathrm{POH}$ protein $(20 \mathrm{nmol})$ was mixed with $\mathrm{HL}-\mathrm{N}(40 \mathrm{nmol})$ in $10 \mathrm{~mL}$ of PBS (pH 8.0) containing $100 \mathrm{mM}$ Tris- $\mathrm{HCl}(\mathrm{pH}$ 8.0) and $3 \mathrm{M}\left(\mathrm{NH}_{4}\right)_{2} \mathrm{SO}_{4}$ for $3 \mathrm{~h}$. Then, the resultant $\mathrm{POH}$ labeled with NIRF dye (POH-N) was purified with a PD-10 gel filtration column (GE Healthcare, Waukesha, WI, USA) and an Amicon-10 centrifugation column (Millipore, Milford, MA, USA). The purified $\mathrm{POH}-\mathrm{N}(2 \mathrm{nmol})$ was finally dissolved in $100 \mu \mathrm{L}$ of PBS ( $\mathrm{pH}$ 8.0). Labeling of POH-Ns was confirmed by SDS-PAGE fluorescence imaging and the labeling rate was calculated as described by the manufacturer's protocol. The labeling rate was constantly $>0.7$.

\section{Animals}

Male Balb/c nu/nu was purchased from Oriental Yeast Co., Ltd (Tokyo, Japan). All mice underwent experiments at 6-10 weeks of age. All animal experiments were performed with approval of the Animal Ethics Committees of Tokyo Institute of Technology (No. 2010008) and in accordance with the Ethical Guidelines for Animal Experimentation of the Tokyo Institute of Technology.

\section{Cell culture conditions}

Human pancreatic cancer SUIT-2 cells were maintained in 5\% FCS-DMEM (Nacalai Tesque, Kyoto, Japan) containing the supplements of penicillin (100 units $/ \mathrm{mL}$ ) and streptomycin $(100 \mu \mathrm{g} / \mathrm{mL})$. All cells were maintained at $37^{\circ} \mathrm{C}$ in $5 \% \mathrm{CO}_{2}$ culture incubator. Mouse renal and liver primary cells were prepared from exerted the kidney and the liver from a FVB mouse purchased from Oriental Yeast Co., Ltd. Primary cells harvested after crashing exerted organs were maintained in $10 \%$ FCS-RPMI (Nacalai Tesque) containing supplements of penicillin (100 units $/ \mathrm{mL})$ and streptomycin $(100 \mu \mathrm{g} / \mathrm{mL})$.

Transplantation of subcutaneous cancer xenografts SUIT-2 cells suspended in PBS $\left(1.0 \times 10^{6}\right.$ cells $\left./ 20 \mu \mathrm{l}\right)$ were mixed with an equal volume of Geltrex (Invitrogen) and injected total volume into both forelegs of 7-weekold male nude mice. Mice with subcutaneous tumors of 5-10 mm in diameter were used for experiments.

\section{In vivo fluorescence imaging}

Two nmol of POH-N in $100 \mu$ l of PBS (pH 8.0) was intravenously injected into tumor-bearing mice. Fluorescence images were acquired at the indicated times. All of the fluorescence images were acquired with IVIS ${ }^{\circledR}$ Spectrum (Caliper Life Sciences, Alameda, CA, USA) using the excitation filter (710 $\pm 15 \mathrm{~nm}$ ), emission filter $(800 \pm 10 \mathrm{~nm})$ for $\mathrm{POH}-\mathrm{P}, \mathrm{POH}-\mathrm{I}$ or emission filter $(780 \pm 10 \mathrm{~nm})$ for $\mathrm{POH}-\mathrm{A}$, exposure time $=1 \mathrm{~s}$, binning = medium (8), field of view $=19 \times 19 \mathrm{~cm}, \mathrm{f} /$ stop $=1$. Fluorescence intensity was analyzed with Living Image 4.0 (Caliper Life Sciences).

\section{Ex vivo fluorescence imaging}

Randomly selected mice were sacrificed after the in vivo imaging and organs were harvested. Fluorescence images 


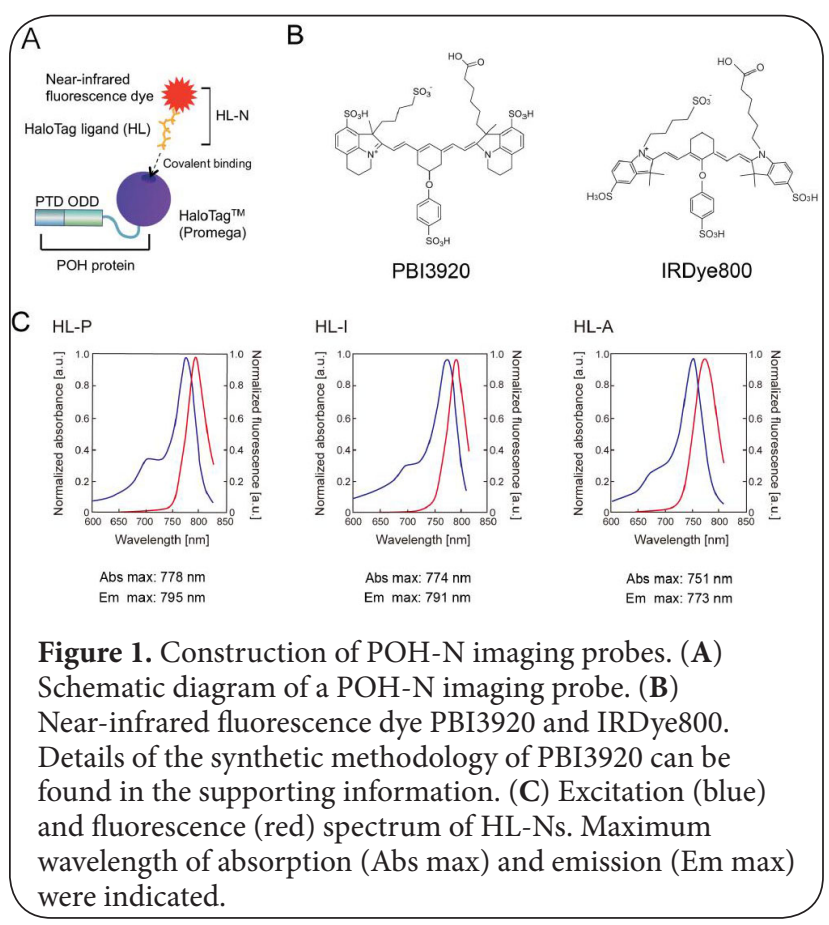

from these organs were obtained with the IVIS Spectrum using the same conditions as in vivo imaging except field of view $=12.9 \times 12.9 \mathrm{~cm}$. Fluorescence intensity was analyzed with Living Image 4.0.

\section{Liquid chromatography analysis}

To analyze the surface charge of HL-Ns, chromatography was performed on an ion-exchange column HiTrap Q HP (GE Healthcare) with a linear gradient from 0 to $2 \mathrm{M} \mathrm{NaCl}$ in Tris- $\mathrm{HCl}(\mathrm{pH} 7.5)$ in $40 \mathrm{~min}$ at a flow rate of $1.0 \mathrm{~mL} / \mathrm{min}$. Hydrophobicity analysis was performed with reversephase column HiTrap Phenyl HP (GE Healthcare) with a linear gradient from 2 to $0 \mathrm{M}\left(\mathrm{NH}_{4}\right)_{2} \mathrm{SO}_{4}$ in $20 \mathrm{mM} \mathrm{HEPES}$ $\mathrm{NaOH}$ (pH 7.5) in $40 \mathrm{~min}$ at a flow rate of $1.0 \mathrm{~mL} / \mathrm{min}$. Retention time of $\mathrm{HL}-\mathrm{N}$ was monitored with absorbance of wavelength $700 \mathrm{~nm}$.

\section{In vitro cellular uptake and excretion assay}

SUIT- 2 cells $\left(2 \times 10^{5}\right.$ cells/well), mouse renal and liver primary cells $\left(2 \times 10^{6}\right.$ cells/well) were seeded with $2 \mathrm{~mL}$ volume in 6-well plates. The cells were preincubated under aerobic condition at $37^{\circ} \mathrm{C}$ for $16 \mathrm{~h}$. After the addition of $500 \mathrm{nM} \mathrm{POH}-\mathrm{N}$ or $5 \mu \mathrm{M} \mathrm{HL}-\mathrm{N}$, the cells were incubated for $1 \mathrm{~h}$. The cells were then washed with fresh medium and suspended in $200 \mu \mathrm{L}$ of radio-immunoprecipitation assay (RIPA) buffer for uptake assessment. Fluorescence measurement was performed with $150 \mu \mathrm{L}$ of cell lysate. For the excretion assay, the cells were washed with fresh growth medium after incubation with $500 \mathrm{nM} \mathrm{POH}-\mathrm{N}$ or $5 \mathrm{mM} \mathrm{HL}-\mathrm{N}$ for $1 \mathrm{~h}$. The cells were then incubated for $1 \mathrm{~h}$ and suspended in $200 \mu \mathrm{L}$ RIPA buffer. Fluorescence measurement was performed for $150 \mu \mathrm{L}$ of suspension in a 96 -well plate by using Infinite ${ }^{\circledR} 500$ plate reader (Tecan, Männedorf, Switzerland) with $740 \mathrm{~nm}$ excitation filter and $780 \mathrm{~nm}$ emission filter. For excretion assay, data were shown as relative NIRF intensity to $0 \mathrm{~h}$ NIRF intensity of each probes.

\section{Statistical analysis}

Data were shown as the mean value plus or minus the standard deviation of the mean. Statistical analyses were carried out with a Student's $t$ test. Values of $p<0.05$ were considered statistically significant.

\section{Results}

\section{Construction of $\mathrm{POH}-\mathrm{N}$ imaging probes}

We previously constructed $\mathrm{POH}$ proteins labeled with IRDye800 (I) or Alexa Fluor750 (A), namely POH-I, or POH-A [15]. NIRF dyes are covalently bound to $\mathrm{POH}$ through $\mathrm{HT}$ and its ligand $(\mathrm{HL})$ reaction, that is each $\mathrm{POH}-\mathrm{N}$ contains one NIRF dye at the specific site (Figure 1A). The in vivo biodistribution and clearance were significantly different between them in tumor-bearing mice, indicating that a small chemical $(\sim 2 \mathrm{kDa})$ influenced the in vivo biodistribution of a large macromolecule ( 46 kDa). We hypothesized that in NIRF dyes there would be a decisive factor that influenced the in vivo behavior of MPMs. Because precise structure of Alexa Fluor 750 is publically unknown, in order to explore the influence of a NIRF dye on the in vivo images after injection of a POH-N, we newly synthesized a NIRF dye, PBI3920, which has very similar chemical structure and size to IRDye800 (Figure 1B). First, $\mathrm{HL}$ was conjugated to NIRF dyes. The resultant HL-NIRF dyes (i.e., HL-P, HL-I, and HL-A) had almost identical excitation and emission wavelengths (Supplement figure S3A and 1C). Then HL-Ns were covalently bound to $\mathrm{POH}$ and the resultant $\mathrm{POH}-\mathrm{Ns}$ (i.e., $\mathrm{POH}-\mathrm{P}, \mathrm{POH}-\mathrm{I}$ and $\mathrm{POH}-\mathrm{A}$ ) were analyzed by SDS-PAGE, confirming that the $\mathrm{POH}-\mathrm{N}$ preparations did not contain any obvious side products (Supplement figure S3B) and that the absorbance and fluorescence spectra of $\mathrm{POH}$ Ns were almost identical to those of corresponding $\mathrm{HL}-\mathrm{Ns}$.

\section{Differential in vivo fluorescent image of POH-Ns in tumor-bearing mice}

$\mathrm{POH}-\mathrm{Ns}$ (i.e., $\mathrm{POH}-\mathrm{P}, \mathrm{POH}-\mathrm{I}$, and $\mathrm{POH}-\mathrm{A}$ ) were intravenously administrated to mice carrying subcutaneous SUIT-2 xenografts, and time-course analysis of in vivo imaging was performed. In spite of structural similarities, in vivo images of $\mathrm{POH}-\mathrm{P}$ and $\mathrm{POH}-\mathrm{I}$ was significantly different first $12 \mathrm{~h}$ after administration: $\mathrm{POH}-\mathrm{I}$ showed a faster clearance than $\mathrm{POH}-\mathrm{P}$; $\mathrm{POH}-\mathrm{A}$ was circulating for longer period of time and cleared slower than others (Figure 2A). Although all of the $\mathrm{POH}-\mathrm{Ns}$ were slowly cleared from tumors, the relative fluorescence intensity of the tumor to muscle (T/M) ratio was significantly different among them $24 \mathrm{~h}$ after administration (Figure 2B). In vitro assay using SUIT-2 cells revealed that $\mathrm{POH}-\mathrm{P}$ entered cells at the lowest rate and was quickly released from cells (Figure 2C). On the other hand, $\mathrm{POH}-\mathrm{A}$ showed the highest rates of entering the cells and slowest cellular clearance 


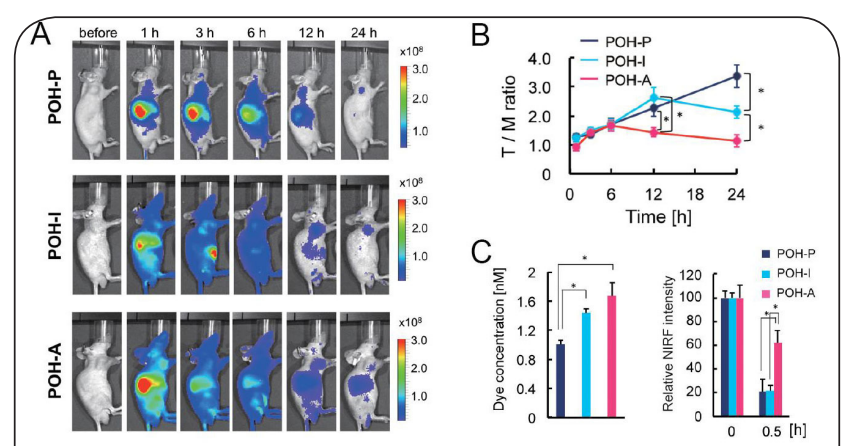

Figure 2. In vivo tumor imaging with $\mathrm{POH}-\mathrm{Ns}$. (A)

Representative in vivo images after administration of $2 \mathrm{nmol}$ POH-P, POH-I and POH-A. Nude mice carrying SUIT-2 xenografts in both forefeet were imaged at the indicated time points after injection of the probes. (B) The relative fluorescence intensity of the tumor to muscle (T/M ratio). Fluorescence intensities of the SUIT-2 xenografts and the muscle of the hind foot were measured at the indicated time points after each $\mathrm{POH}-\mathrm{N}$ administration $(\mathrm{n}=6) .{ }^{*} \mathrm{p}<0.05$. (C) Uptake (left panel) and residual (right panel) of $\mathrm{POH}-\mathrm{Ns}$ in SUIT-2 $(\mathrm{n}=3) .{ }^{*} \mathrm{p}<0.01$.

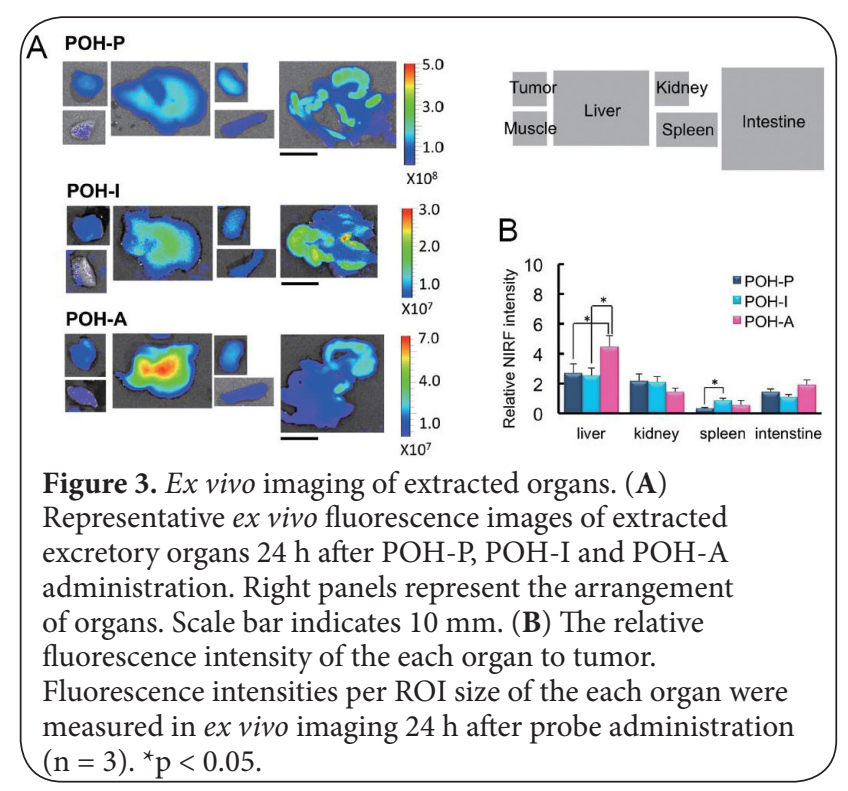

among the three $\mathrm{POH}-\mathrm{Ns}$ (Figure 2C).

Ex vivo imaging analysis of excretory organs such as the liver, kidneys, and intestines was performed $24 \mathrm{~h}$ after $\mathrm{POH}$ Ns administration because strong signals were observed in the abdominal region of the $\mathrm{POH}-\mathrm{A}$-injected mice (Figure 2A). Semiquantitative analysis of the relative fluorescence intensity in each organ revealed that a significant amount of $\mathrm{POH}-\mathrm{A}$ was located in the liver $24 \mathrm{~h}$ after administration (Figure 3A and B). More detailed in vivo imaging analyses indicated that although all of the $\mathrm{POH}-$ $\mathrm{Ns}$ accumulated in the liver $1 \mathrm{~h}$ after administration, the clearance speed of $\mathrm{POH}-\mathrm{A}$ was the slowest; the clearance speed of $\mathrm{POH}-\mathrm{P}$ was relatively slower than that of $\mathrm{POH}-\mathrm{I}$ (Figure 4A and Supplement figure S4A). POH-I was cleared
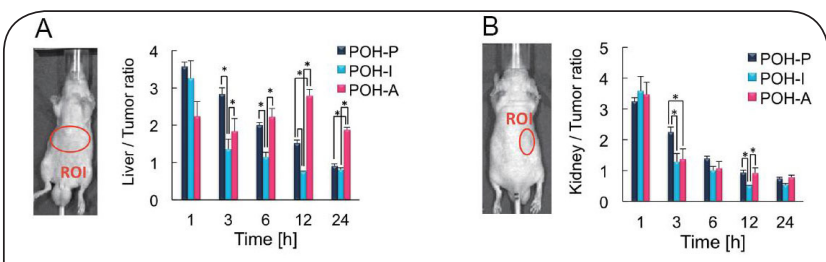

Figure 4. Pharmacokinetic analysis of POH-Ns. (A) Semiquantitative analysis of fluorescence due to the liver by ROI (Region of Interest) measurement $(n=3)$. (B) Semiquantitative analysis of fluorescence due to the kidney by ROI measurement (bottom panel) $(n=3) .{ }^{*} \mathrm{p}<0.05$
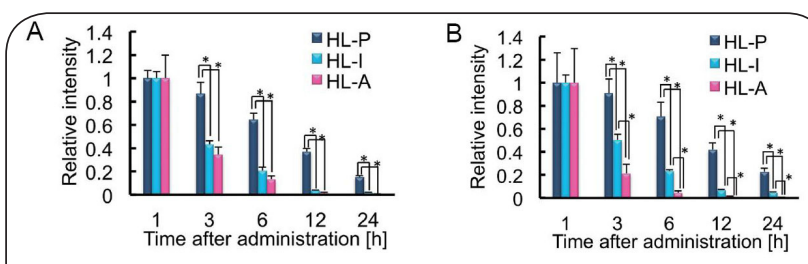

C

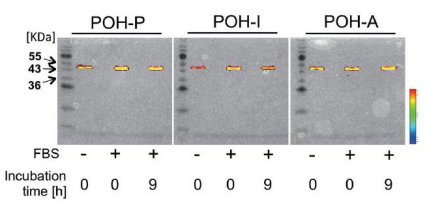

Figure 5. Influence of HL-Ns on in vivo biodistirbution of POH-Ns. (A) Semiquantitative analysis of fluorescence clearance in the liver $(\mathrm{n}=3)(\mathbf{B})$ Semiquantitative analysis of fluorescence clearance in the kidney $(n=3) .{ }^{*} \mathrm{p}<0.05$. (C) Stability of $\mathrm{POH}-\mathrm{Ns}$ under incubation with serum at $37^{\circ} \mathrm{C}$. $\mathrm{POH}-\mathrm{N}$ probes were incubated for indicated times in $50 \%$ FCS-PBS at $37^{\circ} \mathrm{C}$. Samples resolved by SDS-

PAGE were fluorescently scanned by IVIS Spectrum with excitation filter: $710 \pm 15 \mathrm{~nm}$, emission filter: $800 \pm 10 \mathrm{~nm}$ for POH-P and POH-I or emission filter: $780 \pm 10 \mathrm{~nm}$ for POH-A.

from the kidneys faster than both $\mathrm{POH}-\mathrm{P}$ and $\mathrm{POH}-\mathrm{A}$ (Figure 4B and Supplement figure S4B). These data indicate that fluorescence dyes significantly influence the in vivo images after injection of $\mathrm{POH}-\mathrm{Ns}$.

\section{Influence of $\mathrm{POH}-\mathrm{N}$ degradation on the in vivo image of $\mathrm{POH}-\mathrm{N}$ probes}

A previous study indicates that most $\mathrm{POH}$ protein is degraded in and excreted from non-target cells $3 \mathrm{~h}$ after entering the cells [15] and that PTD-ODD fusion protein probe quickly disappeared from blood flow (only $15 \%$ in blood flow $1 \mathrm{~h}$ after injection and then half-life in blood was approximately $2 \mathrm{~h}$ ) [19]. Therefore, we investigated whether the differential off-target images after injection of $\mathrm{POH}-\mathrm{Ns}$ in vivo are caused by intact $\mathrm{POH}-\mathrm{Ns}$ or $\mathrm{HL}-\mathrm{Ns}$ derived from degraded $\mathrm{POH}-\mathrm{Ns}$. HL-N exhibited clearly different in vivo images from the corresponding $\mathrm{POH}-\mathrm{N} ; \mathrm{HL}-\mathrm{I}$ and $\mathrm{HL}-\mathrm{A}$ did not accumulate in the liver or kidneys soon after injection; however, the clearance speed of HL-P was relatively slower 
Kuchimaru et al. Journal of Pharmaceutical Technology \& Drug Research 2013, http://www.hoajonline.com/journals/pdf/2050-120X-2-2.pdf

Table 1. Retention time of chromatograph analyses of HL-Ns. IEC: ion-exchange chromatograph, RPC: reverse-phase chromatograph.

\begin{tabular}{lccc}
\hline HL-N & $\begin{array}{c}\text { Ion-exchange } \\
\text { chromatograph } \\
\text { (min) }\end{array}$ & $\begin{array}{c}\text { Reverse-phase } \\
\text { chromatograph } \\
\text { (min) }\end{array}$ & Ratio of IEC to RPC \\
\hline HL-P & 16.5 & 34.8 & 0.474 \\
HL-I & 14.3 & 34.6 & 0.413 \\
HL-A & 13.1 & 32.4 & 0.404 \\
\hline
\end{tabular}

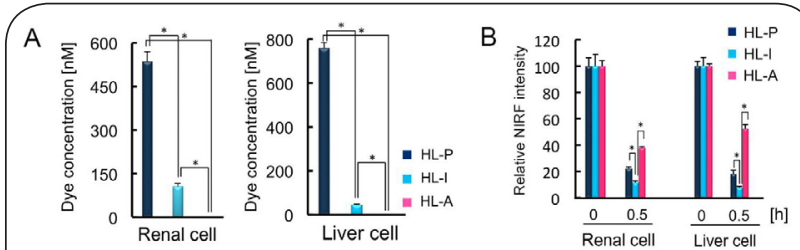

Figure 6. Cellular uptake and excretion of HL-Ns. (A) Uptake of HL-Ns in mouse primary renal cells, liver cells $(\mathrm{n}=3)$. (B) Clearance speed of HL-Ns from mouse primary renal cells, liver cells $(n=3) .^{\star} \mathrm{p}<0.05$.

than that of HL-I and HL-A in both the liver and kidneys (Figure 5A, 5B and Supplement figure S5). All POH-Ns were stable after $9 \mathrm{~h}$-incubation with serum at $37^{\circ} \mathrm{C}$ (Figure $5 \mathrm{C}$ ). These findings, together with our previous study, indicate that the behavior of $\mathrm{HL}-\mathrm{Ns}$ detached from $\mathrm{POH}$ would cause off-target fluorescent image in the excretory organs.

\section{Chromatographic analysis and cell penetration efficiency of HL-Ns}

To elucidate a possible factor in $\mathrm{HL}-\mathrm{N} s$ influencing the in vivo biodistribution of $\mathrm{POH}-\mathrm{Ns}$, we analyzed the surface charge and hydrophobicity of HL-Ns by ion-exchange and reverse-phase liquid chromatography. Even though HL-P and $\mathrm{HL}-\mathrm{I}$ have the same net charge of -3 , long retention time of $\mathrm{HL}-\mathrm{P}$ in ion-exchange liquid chromatograph indicates that HL-P possesses a larger effective charge moment induced by the distribution of negative charge than either HL-I or HL-A. Short retention time of HL-A in reverse-phase liquid chromatograph indicates that $\mathrm{HL}-\mathrm{A}$ is overall more hydrophilic than either HL-P or HL-I (Table 1).

Next, we assessed HL-Ns in the rate of uptake and cellular clearance with primary mouse renal and liver cells (Figure 6A and 6B). Larger amounts of HL-P entered the primary cells than HL-I (Figure 6A), while HL-P was released from cells more slowly than $\mathrm{HL}-\mathrm{I}$ (Figure 6B). Furthermore, $\mathrm{HL}-\mathrm{A}$ had significantly less cell membrane permeability and a slower diffusion rate than both HL-P and $\mathrm{HL}-\mathrm{I}$ (Figure $6 \mathrm{~A}$ and $6 \mathrm{~B}$ ). These results suggest that the physicochemical properties of fluorescence dyes such as electrical charge distribution and relative hydrophobicity strongly influence the rate of entering and diffusing from cells. Furthermore, fluorescent PTD probes must take into account the influence of the properties of dyes released from the probes with respect to the proper evaluation of the in vivo biodistribution of the probes.

\section{Discussion}

Information for in vivo biodistribution of MPMs is valuable for developing novel diagnostic and therapeutic agents specific to disease-related molecules inside cells. To our knowledge, this is the first report describing the physicochemical properties of small chemicals that significantly influence the in vivo images of MPMs. For MPM imaging probes, quick clearance of the off-target signals from the non-targeted tissue cells as well as the excretory organs is important to achieve high target-specific imaging in living animals. $\mathrm{POH}-\mathrm{P}$ showed the highest T/M ratio $24 \mathrm{~h}$ after its intravenous administration. The results of in vitro assay of $\mathrm{POH}-\mathrm{N}$ using cancer cells were not necessarily correlated with the T/M ratio, which is one of the parameters of target specificity (Figure 2B and 2C). One of the reasons of this discrepancy is probably that tumors are composed of wide variety of cells such as endothelial cells, stromal cells and blood cells and that the rates of uptake and cellular clearance are different among the cell types. In other words, results obtained by in vitro assays using cancer cells do not always provide proper information of in vivo target-specificity of MPMs.

Off-target fluorescence signal is common problem for in vivo optical imaging. Reduction of off-target signal of imaging probes based on a nanoparticle and antibody mostly depends on their excretion pathway [20,21]. Renal excretion is generally promoted when an MPM can go through size and charge filtration in the kidneys $[22,23]$. Meanwhile, large or lipophilic molecules tend to be trapped in the liver $[24,25]$. Although all of the $\mathrm{POH}-\mathrm{Ns}$ accumulated in the kidneys and liver soon after administration, their clearance speed from these organs differed (Figure 2A). The accumulation of $\mathrm{POH}-\mathrm{Ns}$ in the kidneys is consistent with the results of previous studies in which the permeable nature of the cell membranes promoted the accumulation of imaging probes in the kidneys due to their absorption into proximal tubules $[26,27]$. Furthermore, $\mathrm{POH}-\mathrm{P}$, in which HL-P has a larger effective charge moment, exhibited relatively slow renal clearance rate compared with $\mathrm{POH}-\mathrm{I}$ or POH-A (Figure 4B). This result compliments those of a recent study in which NIRF dyes with strong surface charges were nonspecifically absorbed in normal tissues [28]. In fact, overall effective charge as measured by ion-exchange chromatography correlates with observations made in vivo. $\mathrm{POH}-\mathrm{Ns}$ differed more drastically with respect to hepatic clearance than renal clearance (Figure 4). POH-P exhibited relatively slower clearance than $\mathrm{POH}-\mathrm{I}$. Unfortunately the structure of Alexa Fluor 750 in $\mathrm{POH}-\mathrm{A}$ is publicly unknown, but the observed chromatography trends for $\mathrm{HL}-\mathrm{A}$ indicate it is more hydrophilic but less charged. However we observed in vivo that both $\mathrm{POH}-\mathrm{A}$ and $\mathrm{HL}-\mathrm{A}$ tended to accumulate in the liver.

Many studies with primary hepatocytes indicate that the physicochemical properties of small molecule xenobiotics 
Kuchimaru et al. Journal of Pharmaceutical Technology \& Drug Research 2013,

greatly influence the process of hepatic clearance [29-31]. For instance, indocyanine green is a lipophilic and anionic NIRF dye that accumulates in the liver. An experiment with multidrug-resistant-2 (MDR2)-knockout mice shows that indocyanine green is mostly excreted from hepatocytes by MDR2 transporter protein. However, the clearance of some organic anions with different hydrophobicity does not absolutely depend on MDR2 [32]. These results suggest that hydrophobicity influences the hepatic clearance processes, resulting in different clearance rates from the liver among xenobiotic compounds. In our experiment, even though $\mathrm{HL}-\mathrm{A}$ was less lipophilic than $\mathrm{HL}-\mathrm{P}$ or $\mathrm{HL}-\mathrm{I}$, it has a smaller effective charge (Table 1) and the charge to hydrophobicity ratio would help explain the slower clearance of $\mathrm{POH}-\mathrm{A}$ from the liver (Figure 4A). Conversely, although there were no significant differences between $\mathrm{HL}-\mathrm{P}$ and $\mathrm{HL}-\mathrm{I}$ with respect to their physical property of hydrophobicity (Table 1) and in vitro stability (Figure 5C), their cell membrane permeability (Figure $6 \mathrm{~A}$ ) and systemic clearance speed (Figure 6B) were very different. Again this can be explained by the overall ratio of effective charge to hydrophobicity as measured by simple chromatography methods, where HL-P has the largest such value (Table 1).

Although the number of NIRF dyes investigated here was limited and although there would be more factors that influence in vivo biodistribution of MPMs, here we demonstrate that a subtle difference in a small chemical component influences in vivo biodistribution of a large MPM. This study might be useful to establish general methodology of rational design of MPM imaging probes. However, to explain detail mechanism of differential images among $\mathrm{POH}-\mathrm{Ns}$, we might have to consider other physicochemical properties besides surface charge and hydrophobicity. Further studies of the correlation between the physicochemical properties of a fluorescent dye and in vivo biodistribution of MPM will be needed to give a generality for designing MPM imaging probes.

\section{Conclusions}

We demonstrated the significance of the physicochemical properties of fluorescence dye components for obtaining target-specific images by MPM imaging probes. Although MPM imaging probes are very promising for advancing the in vivo imaging of molecular targets of various diseases, no reports indicate decisive factors for improving targetspecific in vivo images of such probes. This study provides insights into more rational design of MPM imaging probes possessing high target-specificity in vivo.

\section{Additional files}

Supplement figures S1-S5

Competing interests

Authors T. Kuchimaru, T. Kadonosono, S. Takahashi, T.
Mori, Y. Okahata and S. Kizaka-Kondoh have no conflict of interest. Authors C. Corona, S. J. Dwight and M. McDougall research was funded by Promega Biosciences LLC.

\section{Acknowledgement}

We are grateful to Shigeaki Watanabe and Machiko Horiuchi (Summit Pharmaceuticals International Corporation,

Tokyo, Japan) for technical support of IVIS and Kiyoshi Sasakura, Dr. Kenjiro Hanaoka and Dr. Tetsuo Nagano (The University of Tokyo, Tokyo, Japan) to measure near-infrared fluorescence spectrum of $\mathrm{POH}-\mathrm{Ns}$. This work was supported by a Grant-in-Aid for Scientific Research on Innovative Areas "Integrative Research on Cancer Microenvironment Network" (22112009 to S.K.K.) from the Ministry of Education, Culture, Sports, Science, and Technology of Japan.

Publication history

Received: 8-Dec-2012 Revised: 24-Dec-2012

Accepted: 30-Dec-2012 Published: 09-Jan-2013

\section{References}

1. Weissleder R and Pittet $M$ J: Imaging in the era of molecular oncology. Nature 2008, 452:580-9. | Article | PubMed Abstract | PubMed Full text

2. Alford R, Ogawa M, Choyke P L and Kobayashi H: Molecular probes for the in vivo imaging of cancer. Mol Biosyst 2009, 5:1279-91. | Article | PubMed Abstract I PubMed Full Text

3. Olafsen T, Kenanova V E, Sundaresan G, Anderson A L, Crow D, Yazaki P J, Li L, Press M F, Gambhir S S, Williams L E, Wong J Y, Raubitschek A $A$, Shively J E and Wu A M: Optimizing radiolabeled engineered antip185HER2 antibody fragments for in vivo imaging. Cancer Res 2005, 65:5907-16. | Article | PubMed

4. Venisnik K M, Olafsen T, Gambhir S S and Wu A M: Fusion of Gaussia luciferase to an engineered anti-carcinoembryonic antigen (CEA) antibody for in vivo optical imaging. Mol Imaging Biol 2007, 9:26777. | Article | PubMed

5. Schwarze S R, Ho A, Vocero-Akbani A and Dowdy S F: In vivo protein transduction: delivery of a biologically active protein into the mouse. Science 1999, 285:1569-72. I Article | PubMed

6. Futaki S, Suzuki T, Ohashi W, Yagami T, Tanaka S, Ueda K and Sugiura Y: Arginine-rich peptides. An abundant source of membranepermeable peptides having potential as carriers for intracellular protein delivery. J Biol Chem 2001, 276:5836-40. I Article I PubMed

7. Gump J M and Dowdy S F: TAT transduction: the molecular mechanism and therapeutic prospects. Trends Mol Med 2007, 13:443-8. I Article I PubMed

8. Kizaka-Kondoh S, Itasaka S, Zeng L, Tanaka S, Zhao T, Takahashi Y, Shibuya K, Hirota K, Semenza G L and Hiraoka M: Selective killing of hypoxia-inducible factor-1-active cells improves survival in a mouse model of invasive and metastatic pancreatic cancer. Clin Cancer Res 2009, 15:3433-41. | Article | PubMed

9. Torchilin V P, Levchenko T S, Rammohan R, Volodina N, Papahadjopoulos-Sternberg B and D'Souza G G: Cell transfection in vitro and in vivo with nontoxic TAT peptide-liposome-DNA complexes. Proc Natl Acad Sci U S A 2003, 100:1972-7. | Article | PubMed Abstract I PubMed Full Text

10. Eguchi A, Meade B R, Chang Y C, Fredrickson C T, Willert K, Puri N and Dowdy S F: Efficient siRNA delivery into primary cells by a peptide transduction domain-dsRNA binding domain fusion protein. Nat Biotechnol 2009, 27:567-71. | Article I PubMed Abstract I PubMed Full Text

11. Wunderbaldinger $P$, Josephson $L$ and Weissleder R: Tat peptide directs enhanced clearance and hepatic permeability of magnetic nanoparticles. Bioconjug Chem 2002, 13:264-8. I Article I PubMed

12. Santra S, Yang H, Dutta D, Stanley J T, Holloway P H, Tan W, Moudgil B $\mathrm{M}$ and Mericle R A: TAT conjugated, FITC doped silica nanoparticles for bioimaging applications. Chem Commun (Camb) 2004, 2810-1. | 


\section{Article | PubMed}

13. Weissleder $R$ and Ntziachristos V: Shedding light onto live molecular targets. Nat Med 2003, 9:123-8. | Article | PubMed

14. Luo S, Zhang E, Su Y, Cheng T and Shi C: A review of NIR dyes in cancer targeting and imaging. Biomaterials 2011, 32:7127-38. Article | PubMed

15. Kuchimaru T, Kadonosono T, Tanaka S, Ushiki T, Hiraoka M and Kizaka-Kondoh S: In vivo imaging of HIF-active tumors by an oxygendependent degradation protein probe with an interchangeable labeling system. PLoS One 2010, 5:e15736. | Article | PubMed Abstract | PubMed Full Text

16. Semenza G L: Targeting HIF-1 for cancer therapy. Nat Rev Cancer 2003, 3:721-32. | Article | PubMed

17. Cai S R, Xu G, Becker-Hapak M, Ma M, Dowdy S F and McLeod H L: The kinetics and tissue distribution of protein transduction in mice. Eur J Pharm Sci 2006, 27:311-9. | Article | PubMed

18. Jarver $P$, Mager I and Langel $U$ : In vivo biodistribution and efficacy of peptide mediated delivery. Trends Pharmacol Sci 2010, 31:528-35. | Article I PubMed

19. Kudo T, Ueda M, Kuge Y, Mukai T, Tanaka S, Masutani M, Kiyono Y, Kizaka-Kondoh S, Hiraoka M and Saji H: Imaging of HIF-1-active tumor hypoxia using a protein effectively delivered to and specifically stabilized in HIF-1-active tumor cells. J Nucl Med 2009, 50:942-9. | Article I PubMed

20. Choi H S, Liu W, Misra P, Tanaka E, Zimmer J P, Itty Ipe B, Bawendi M G and Frangioni J V: Renal clearance of quantum dots. Nat Biotechnol 2007, 25:1165-70. | Article | PubMed Abstract | PubMed Full Text

21. Wu A M and Senter P D: Arming antibodies: prospects and challenges for immunoconjugates. Nat Biotechnol 2005, 23:1137-46. | Article | PubMed

22. Chang R L, Ueki I F, Troy J L, Deen W M, Robertson C R and Brenner B M: Permselectivity of the glomerular capillary wall to macromolecules. II. Experimental studies in rats using neutral dextran. Biophys J 1975, 15:887-906. | Article | PubMed Abstract | PubMed Full Text

23. Rennke H G, Patel Y and Venkatachalam M A: Glomerular filtration of proteins: clearance of anionic, neutral, and cationic horseradish peroxidase in the rat. Kidney Int 1978, 13:278-88. | Article | PubMed

24. Seydel J K and Schaper K J: Quantitative structure-pharmacokinetic relationships and drug design. Pharmacol Ther 1981, 15:131-82. | Article | PubMed

25. Zhang X D, Wu D, Shen X, Liu P X, Yang N, Zhao B, Zhang H, Sun Y M, Zhang $L A$ and Fan $F Y$ : Size-dependent in vivo toxicity of PEG-coated gold nanoparticles. Int J Nanomedicine 2011, 6:2071-81. | Article | PubMed Abstract | PubMed Full Text

26. Kobayashi H, Le N, Kim I S, Kim M K, Pie J E, Drumm D, Paik D S, Waldmann T A, Paik CH and Carrasquillo J A: The pharmacokinetic characteristics of glycolated humanized anti-Tac Fabs are determined by their isoelectric points. Cancer Res 1999, 59:422-30. | Article I PubMed

27. Kameyama S, Horie M, Kikuchi T, Omura T, Takeuchi T, Nakase I, Sugiura $Y$ and Futaki S: Effects of cell-permeating peptide binding on the distribution of 125I-labeled Fab fragment in rats. Bioconjug Chem 2006, 17:597-602. I Article I PubMed

28. Choi H S, Nasr K, Alyabyev S, Feith D, Lee J H, Kim S H, Ashitate Y, Hyun $H$, Patonay G, Strekowski L, Henary M and Frangioni J V: Synthesis and in vivo fate of zwitterionic near-infrared fluorophores. Angew Chem Int Ed Eng/ 2011, 50:6258-63. | Article | PubMed Abstract | PubMed Full Text

29. Austin R P, Barton P, Mohmed S and Riley R J: The binding of drugs to hepatocytes and its relationship to physicochemical properties. Drug Metab Dispos 2005, 33:419-25. | Article | PubMed

30. Betts A, Atkinson F, Gardner I, Fox D, Webster R, Beaumont K and Morgan P: Impact of physicochemical and structural properties on the pharmacokinetics of a series of alpha1L-adrenoceptor antagonists. Drug Metab Dispos 2007, 35:1435-45. | Article | PubMed
31. Luo G, Johnson S, Hsueh M M, Zheng J, Cai H, Xin B, Chong S, He K and Harper T W: In silico prediction of biliary excretion of drugs in rats based on physicochemical properties. Drug Metab Dispos 2010, 38:422-30. | Article | PubMed

32. Huang $L$ and Vore $M$ : Multidrug resistance $p$-glycoprotein $\mathbf{2}$ is essential for the biliary excretion of indocyanine green. Drug Metab Dispos 2001, 29:634-7 | Article | PubMed

\section{Citation:}

Kuchimaru T, Kadonosono T, Corona C, Dwight S J, McDougall M, Takahashi S, Mori T, Okahata $\mathrm{Y}$ and Kizaka-Kondoh S: Importance of the physicochemical properties of fluorescent dyes for obtaining target-specific in vivo images by membrane-permeable macromolecular imaging probes. journal of Pharmaceutical Technology and Drug Research 2013, 2:2.

http://dx.doi.org/10.7243/2050-120X-2-2 